\title{
Kapitalizmin Sosyolojik Temelleri Üzerine Bir İnceleme: Marx, Weber ve Ülgener Karşılaştırması ${ }^{1}$
}

\author{
An Examination of the Sociological Foundations of Capitalism: Comparing Marx, Weber and \\ Ülgener
}

Habibe KULLE

Öğr. Grv., Hatay Mustafa Kemal Üniversitesi, Kırıkhan MYO, Yönetim ve Organizasyon Bölümü, hbb_kll_64@hotmail.com

https://orcid.org/0000-0002-4027-0684
Makale Başvuru Tarihi: 24.10.2019

Makale Kabul Tarihi: 31.12.2019

Makale Türü: Araştırma Makalesi

\section{Anahtar \\ Kelimeler: \\ Karl Marx, \\ Max Weber, \\ Sabri Fehmi \\ Ülgener,}

Kapitalistleşmeme Sorunu,

\section{Keywords:}

Karl Marx,

Max Weber,

Sabri Fehmi

Ülgener,

The problem of non-capitalization

\section{ÖZET}

Bu çalışma, Sabri Fehmi Ülgener'in Doğu toplumlarının kapitalistleşememe sorununu ele alması üzerine yapılmış olan bir incelemedir. Buradaki amaç, Ülgener'in Doğunun kapitalistleşememesi sorununu nasıl değerlendirdiğini ve bu de ğerlendirme sonucunda elde ettiği bulgular ile sosyolojiye să̆ladı̆g katkıları tespit etmektir. Bu bağlamda, Marx’ın pozitivizm ve maddeyi kullanarak kapitalizmin gelişimini tanımlayarak açıklayan düşünceleri kullanılmıştır. Takibinde kapitalizme yönelik açıklamaları ile sosyoloji alanına büyük katkılar yapan Weber'in de bu konudaki düşüncelerine değinilmiştir. Ayrıca bu iki düşünürün kapitalizm ve Doğunun kapitalistleșememesine ilişkin düşünceleri de Ülgener'in düşünceleri ile karşılaştırılarak yeniden değerlendirmiştir. Yine Ülgener'in Doğunun kapitalistleşememesine yönelik yaptığı açıklamaları ile aşkın felsefe anlayışına eleştirel bir gözle bakılmasını sağlamıştır. Ülgener'in açıklamalarlyla, içkin bir felsefe anlayışının gerekliliğine de ulaşılmıştır. Ayrıca çalışma sosyolojik sorunları değerlendirirken yararlanılan metotun da önemli olduğunu göstermektedir. Çallşmanın hazırlanmasında yöntem olarak, tarihsel ve betimleyici yöntemden yararlanılmıştır. Bu çalış̧ma yazarın 2017 yılında Karamanoğlu Mehmetbey Üniversitesi Sosyal Bilimler Enstitüsü tarafindan kabul edilen "Benedictus De Spinoza
Öncülügünde Siyasetin Aşkinlıktan İçkinliğe Yeniden Tanımlanması" konulu yüksek lisans tezinden yararlanılarak hazırlanmıştır. 


\section{GIRISS}

Türk siyaset hayatında ve bürokrasi yapısında dikkat çeken olaylar, tarihsel süreçteki ekonomik ve toplumsal buhranlardır. Bu buhranlar genel anlamıyla siyasi alanda mevcut olan yönetilemezlik ve temsil krizleri, toplumsal alanda da bunların yansıması olan siyasete ilgilizlik, siyasal şiddet olarak karşımıza çıkmaktadır. Ekonomik konjüktürde de yer alan genişleyici ve daraltıcı politikaların etkisiyle birlikte bu durumlar daha da gerici hale gelebilmektedir. Fakat burada önemli olan şeylerden bir tanesi de gerek siyasi alanın gerekse toplumsal alanın ortak kaygısını oluşturan belirsizlik ve anlaşılamama korkusudur. $\mathrm{Bu}$ sorunların ise hangi alandan hareketle çözüme kavuşturulacağı ise hale tartışılmaktadır.Tarihi alandan mı, bürokratik yapıdan mı yoksa ekonomik konjonktüre bağlı olarak mı ele almalıyız bu önemli bir sorun oluşturmaktadır. Bununla birlikte hangi alana öncelik vererek ya da öncelik verilmesi gerekiyor mu soruları da ayrı bir tartışma konusu oluşturmaktadır. Bu üç soruya da verilen farklı cevaplar beraberinde yeni ve farklı sorunları da getirmektedir. $\mathrm{Bu}$ açmazın ve bu alanların ortak noktasının nerede kesiştiği meselesi iktisadi ve sosyal alanda kördüğüm oluşturmaktadır. Sabri Fehmi Ülgener de bu sorunlar hakkında çalışmış ve bu üç alanı da içerisine alan kapitalistleşememe sorunu üzerinde düşüncelerini yoğunlaştırmıştır. Ortak noktayı da sahip olunan iktisat zihniyeti ile iktisat ahlakını bir birinden ayırarak ele almanın gerekliliği ile keşfetmiştir.

Benzer sorunu, Batılı düşünürlerden Karl Marx ve Max Weber ise daha çok edindikleri metodolojilerden hareketle ve kendi coğrafyalarının zihniyet ve ahlakından hareketle ele almışlardır. Bu durumun farkına varan Ülgener, sorunun çözümü noktasında da tek bir kanattan değil üç alanı da içerisine alacak kapsamlı bir alandan hareket etmiştir. Bunun için de aradığı metodu dönemin Durkheimci/Gökalpci pozitivist anlayışında değil Alman Tarih Okulu hocalarında ve bilhassa da Weber'den etkilenerek edindiği anlamacı (anlayış) metotta bulmuştur. Ona göre sadece ekonomik, sosyal ya da tarihsel sürece ve bunların somut göstergelerine bakarak bu dügümün çözülmesi imkansızdır. Bunun için o dönemlere ve o dönemdeki tüm bu faaliyetlerin ortaya çıkmasını sağlayan zihniyet olgusunu, zihinsel sürecini de incelemek gerekmektedir. Çünkü sosyal bilimler ve sosyolojik alan onları oluşturan insan ögesinden bağımsız değildir. Fen bilimleri gibi doğa bilimlerinde kullanılan metotlarla açıklanamayacak kadar da karmaşık bir yapıya sahiptir. Bu nedenle de sadece salt insan unsurundan değil onun edindiği zihinsel alanı ve bu zihinselliğin yansıması olan ahlaki alanı anlayarak olayları ele almak gerekmektedir. Bunun için de içerisinde insan ögesini barındıran tüm olgulardan yararlanılmalıdır. Özelliklede tarih alanında ve edebi alanda verilmiş olan yapıtlara gerekli önem verilmelidir. Çünkü bu eserler insan zihninin en objektif ve saf haliyle yansıtıldığı olgulardır. Buradan hareketle Ülgener, Doğunun kapitalistleşememe sorununu Marx ve Weber'e paralel olarak ele almıştır. Ancak o diğer iki düşünürün konu sınırlamaları husunda uymadıkları zaman sınırlaması hususunu da dikkate alarak araştırmasını Osmanlı devleti döneminden başlayıp, Cumhuriyet tarihi sürecine kadar olan iktisadi yapıyı da ele alarak meydana getirmiştir.

$\mathrm{Bu}$ çerçeve de yazıda öncelikle kapitalistleşememe olgusunun Batıdaki ve Doğudaki temellerinin düzgün bir şekilde ele alınması için mevcut sorunu ele alan düşünürlerin edindikleri metotlara yer verilmiştir. Daha sonra ise kapitalistleşememe sorununu ele alan Batıll düşünürler olarak Marx ve Weber'in düşünceleri ile Ülgener'in bu konuyu ele almasına yer verilmiştir. Son olarak üçüncü bölümde de Sabri Fehmi Ülgener'in kapitalistleşememe olgusu hakkında Marx ve Weber'in yaptığı açıklamalara getirmiş olduğu eleştirilerle birlikte, kendisinin de eleştirilen yönlerine yer verilmiştir. Böylece sosyal bilimler alanında çalışırken karşılaşılacak sapmaların neler olabileceği gösterilmeye çalışılmaktadır ve aynı zamanda Ülgener'in düşünce sistemi ile dünya felsefesine yaptığı bir çok katkısı da tespit edilmeye çalışılmıştır.

\section{ANLAMACI YÖNTEM VE AÇIKLAYICI YÖNTEM}

Yöntemsel analizle konuya başlamaktaki temel amaç, düşünürlerin felsefelerini oluştururken faydalandıkları metotları kavrayıp onların felsefeleri incelenirken yanılsamalardan kurtulmaktır.Bu nedenle öncelik olarak dolayı Marx'ın metodolojisi olan açıklayıcı yöntem ele alınmış ve arkasından Weber ve ondan etkilenerek Ülgener'in de benimsediği açıklayıcı metoda değinilmiştir.

\subsection{Açıklayıcı Yöntem}

Açıklayıcı yöntem, doğa bilimlerinde kullanılan yöntemlerin toplum bilimlerine de uygulanmasını öngörür. Yani toplumsal alanında bir tür deneylenebilir ve ölçülebilir bir alan olduğunu varsayarak, toplumsal alanı tamamen pozitivizme dayalı olarak ele almaya çalışmaktadır. Ancak Marx, bu yöntemi tamamen ampirik bir 
süreçler dizisi şeklinde ele almamıştır ve felsefesine de bu şekilde uyarlamamıştır. O yöntemini aposteriori düşünce geliştirme yöntemi olarak tasavvur etmiştir. Yani o salt aklın eleştirisine dayanan bir pozitivizmin belirleyiciliğinden daha farklı bir yöntem düşünmüştür. Bu yönüyle de Marx, Hegel'in bir sentez ile son bulan katı diyalektik anlayışından da kurtulabilmiştir. Onun için diyalektik bir düşünme şeklidir. Bu düşünce şeklinde de akıl ve Tanrı sadece ide de tanımlanamaz. Çünkü, Marx için insan yaşamı sürekli bir akış içerisindedir. Bu akış da salt bir kuram ile değil onun uygulama alanı olan pratiğinde yer aldığı bir birliktelikte akmaktadır. Bu birliktelik alanı da tarihselliktir. Bundan dolayı tarih ögesi Marx için önemlidir. Çünkü tarih insan aklının şekillendiği bir alandır. Onun araştırma yöntemi soyuttan somuta doğru gitmektedir. O yönteminde nicel ve niteliksel gözlemle elde ettiği verileri tam bir şekilde kullanmıştır. Bu verilerden hareket ederek sosyal alanı açıklamaya çalışmıştır. Bunu yaparken de yine sürekli olarak sosyal yaşamdan gözlemle kuramsal inşa oluşturacak veriler elde etmiştir. Böylece o bu kurumsal verileri sosyal gerçeklik ile ilişkilendirerek gerçekliği yakalamaya çalışmıştır (Erdoğan, 2007:257-258). Deleuze göre aşkın anlayış, iç bütünlüğe sahip olduğu düşünülen kapalı bir sistem içerisinde yer alan her şeyin ama her şeyin asimile edildiği ve böylece tekliğin oluşturularak bütünlüğün vurgulandığı bir sistemdir. Bu sistem içerisinde yer alan her şey özsel yapıları gereğince tanımlanıp, sistem içerisine adapte edilerek, dikey bir sıralamaya, hiyerarşiye tabi tutulmaktadır. Şeylerin önemini de hiyerarşide kapladıkları alan belirlemektedir. Deleuze için bu anlayış rasyonalist temsil ve yorumlamalar ile arzuları belirli bir alanda sabitleyip insanın yaşam mücadelesinin ürünü olan tarihsel alanında ki süreç ve olay kavramlarını ortadan kaldırmaktadır. Böylece aşkın anlayış, yeniliğe kapalı, baskıcı, dayatmaların yer aldığı, zorbalığı ve şiddeti içerisinde barındıran bir yönetimle eş anlamlıdır (Küçükalp, 2009:133).

\subsection{Anlamacı Yöntem}

Anlamac1 yönteme gelindiğinde ise Weber bu yöntemi Dilthey'in doğa bilimleri ile toplum bilimlerini incelerken farklı metotların kullanılmasına yönelik, Kant’tan etkilenerek oluşturduğu ayrımdan faydalanarak edinmiştir. Dilthey, tin bilimlerinin doğa bilimlerindeki gibi dış gözleme bağlı olan açıklayıcı yöntem ile anlaşılamayacağını savunur. Anlamacı yöntem olayların bir dış gözlem ile değil içe bakış ile iç gözlemle anlamlandırılabileceğini savunur. Burada ki iç gözlem bir tür yeniden üretim ve duygudaşlık (yerine koyarak düşünme) yeteneğine dayanır. Bu anlamda olaylar ve olgular tarihsel düzlemde ait olduğu yere göre ve görüşe göre ele alınıp değerlendirilir (İlhan, 2014:20). Yani anlamacı metot, toplumsal olgu ve olayların doğa bilimlerindeki gibi dış gözleme dayalı, keskin bir nedensellik ile anlaşılabileceği görüşüne karşı çıkan ve onun yerine toplumda meydana gelen fenomenlerin bir tür içe bakış yöntemi ile değerlendirmesi gerektiğini savunan anlayıştır. Weber'in yöntemi de bu anlamda anlamacı yönü ağır basan fakat yer yer yarı pozitivist eğilimlerinden dolayı açıklayıcı metoda da yer veren bir yöntemdir (Zaret, 1980:1181'den akt.: İlhan, 2014:23). Weber'in bu pozitivist eğilimleri de onun bilimselcilik tutkusundan ileri gelmektedir. Yani o söylediklerinin bilimsel bir tutarlı1ık ile desteklenmesi için deneysel bir takım testlerle doğrulanmasını öngörmektedir (Hughes, 1985:269). Weber, "Toplum Biliminde Nesnellik"(1904) adlı denemesinde, kendi yaklaşımını şu şekilde açıklamıştır (Swingewood, 1998:174);

\section{"içinde hareket ettiğimiz gerçekliğin (kendimizin hem "içinde" hem de "dışında" gelişen, birbiri ardı sira ve bir arada ortaya çıkıp görünen "sonsuz çeşitlilikteki olaylardan oluşan bir gerçekliğin" karakteristik tekliğini anlama çerçevesinde kurmuştu".}

Weber'in yönteminde dikkat ettiği bir diğer husus kültürel alanı anlamak konusunda bilimsel yasaların ne kadar yeterli olduğudur. Kültürel alanı ele alırken iki alanın birbirini dışlar nitelikte olduğu görülmektedir. Bilimsel alan deney ve gözleme dayalı olarak daha somut ilerlerken, kültürel alanı anlamak için oluşturuldukları coğrafyayı anlamak gerekir. Bundan dolayı evrensel bir kültür yasası yoktur ve kültür öznel bir yapı ve tarihe sahiptir (İlhan, 2014:25-26). Weber'in metodunda üzerinde durduğu bir diğer nokta ise toplumsal ve tarihsel alanı incelerken değer kavramından ne kadar vazgeçilebildiği ve ne kadar nesnel olunabildiğidir (Baert, 2010:64-66). Bununla birlikte Weber, dinin yerine geçirilebilecek olan, herkesi ve her şeyi kapsayan, her derde deva olabilecek bir hakikatin olmayacağını savunmuştur (Weber, 2006:218-220). Weber'e göre bir sosyal bilimcinin nesnel olması imkansızdır. Çünkü sosyal bilimci araştıracağı nesneyi kendi zihninde daha önceden şekillenen değerlere, kabul ve reddedişlere göre şekillendirir. Çünkü eylemin toplumsallığı, diğerlerinin davranışını dikkate aldığı ölçüde gerçekleşir (Weber, 2012:112). Weber ideal tip kavramı da onun metodolojisinde önemli bir yere sahiptir. Çünkü onun yöntemsel yaklaşımına göre her ideal tip kendi bulunduğu kültürel alana göre farkl1lık göstermektedir (İlhan, 2014:29). İdeal tipler Weber'in "toplumsal eylem" kavramını bilimsel bir alana taşımak ve dünya tarihini oluşturan başat olguları çözümleyebilmek için oluşturduğu akıl ürünü araçlardır. Yani gerçek dünyada rastlanması imkansız olan ama tarihsel ve sosyolojik alanda doğa 
bilimlerinde ki kesinliği değersel alanda da gerçekleştirmek için oluşturulmuşlardır. Bu ideal tiplerin işlevi, gerçek dünyanın anlaşılabilirliğini kolaylaştırmaktır. Bunlar tekil haldeki fenomenlerin özsel bir birlikteliğini sağlarlar ve bu tekilliğin farklı varyasyonlarını ortaya koyarlar (Baert, 2010:72). Sonuç olarak Weber bu ideal tipleri ortaya koyarken yeni bir şeyler üretmek amacında değildir (Weber, 2006:107).

Anlamacı yöntemi Weber'den esinlenerek kullanan ve Türk siyasal hayatında düşünceleriyle önemli bir yer etmiş olan kişi Sabri Fehmi Ülgener'dir. Ülgener'in yöntemi kullanma şekline ve tanımlamada yer verdiği kavramlara dikkat edildiğinde Weber'in izleri görülmektedir. Ülgener, Weber'in sosyal alanı anlamak için faydalandığı anlamacı yöntemini onunla benzer bir şekilde kullanmaya devam etmiştir. Metodunun önemini de toplumsal alanın tamamlayıcısı olan ve somut bir inceleme alanı sunan iktisadi yaşam tarzı üzerine yaptığı açıklamalarında göstermektedir (Sayar, 1998:251).

Ülgener'in yöntemi bu şekilde kullanma nedenini ise onun şu cümleleri açıklamaktadır. Ülgener, bireyin davranış kalıplarının dışarıya yansıdığı haliyle değil de o hareketi sergilemesine neden olan zihni mana ve niyetlerinde ele alınması gerektiğini savunmaktadır. Dışarıdan görünen ne olursa olsun sosyal eylem onun altında yatan bu kasıt ve niyetlerden anlaşılabilmektedir. Araştırmacının da bu anlamda içten dişa doğru bir incelemeye yönelmesi gerekmektedir (Ülgener, 2006c:12-13). Ülgener, iktisat hayatının da bu şekilde ele alınması gerektiğini savunmuştur. Ona göre iktisat hayatı klasik iktisatçıların savunduğu gibi somut olaylar üzerinden ilerleyen bir olgular dünyası değildir. Yine Alman tarihçi hocaların da belirttiği gibi üretimin hukuki, politik çerçevesi ya da işletme, teşebbüs ilişkisi şeklinde de açıklanamaz. İktisadi hayat gerçek hayatta var olan çeşitlilik içinde meydana gelir. Bu anlamda dışarının bu çeşitliliğin içindeki derinliklere inmesi gerekir. Çünkü mevcut durum yüzeyin üzerine resmedilmiş olan şekil ve madde yığını olsa da altta yer alan geniş bir zihniyet ve ruh dünyası bulunmaktadır (Ülgener, 2006b:3-4).

Ülgener analitik okumanın ötesinde sentetik okumaya bağlı olarak düşüncelerini temellendirmiştir. Böylece yılların zihni birikimini dışa vuran tasavvurunu manevi ilimlerin söz ve deyimlerinden, kıssa ve temsillerinden çıkarılabileceğini söylemektedir. Böylece doğa bilimlerinin dış verilerine dayalı olan açıklayıcı metodunun karşısına manevi bilimlerin mana ve esprisini kullanarak anlayıcı metot ile karşı durmaktadır (Ülgener, 2006c:27). Ülgener'in metodunu oluşturan diğer bir olgu, onda Weber'in izlerinin taşıyıcıllı̆̆ını yapan "ideal tip" kavramıdır. Ülgener ideal tip tanımlamasını kapitalistleşememe sorununu ele alırken odaklandığı o zihniyet algısını, biçimini ifade etmek için kullanmıştır. İdeal tip tanımını da şöyle dile getirir (Ülgener, 2006c:56);

\section{"Tarihi-kültürel kompleksleri önce yığın haldeki heterojen unsurlardan soyup aylklayıp iç yapılarından en fazla tutarlı (conseguent) unsurlarına ă̆ırlık vermek suretiyle inşa edilmiş tipler (ideal tipler) halinde taktim etmek!'”.}

Ülgener'in kapitalistleşememe sorunu çözerken kullandığı çözülme devri, ortaçağlaşma ve aydınlarla ilgili oluşturduğu tipolojiler onun ideal tiplerini simgeler. Ülgener'in bu şekilde bir ideal tiplemeye gittiği “ïktisadi Çözülmenin Ahlak ve Zihniyet Dünyası" kitabında bahsettiği, var olan mevcut durumu geçmişin getirdikleri ile yeniden kendi hayalimizdeki şekliyle yaşayabileceğiz, sözünden çıkartılabilir (Ülgener, 2006b:11).

Ülgener, Alman iktisatçılardan etkilenerek kullandığı anlamacı yöntemi kendi tecrübelerinden de edindiği bilgilerle birleştirerek kapitalistleşememe olgusunu bu şekilde açıklamaya çalışmıştır. Metodunu da dönemsel bağlamda ele alarak ve bu dönemlerin zihniyet algısını anlamaya çalışarak gerçekleştirmiştir.Yani dönemindeki Marksist- maddeci okumanın dışında manevi ilimler bağlamında tarihsel bir okumaya dayalı olarak ve her yönüyle maddenin altındaki zihniyeti anlamaya çalışarak yapmıştır. Dönemin fütüvvet ve tasavvuf anlayışını da bir zihniyet sorunu olarak kapitalistleşememenin önünde ki sorun olarak yorumlamıştır (İlhan, 2014:86-94).

\section{MARX, WEBER VE ÜLGENER'İN SOSYOLOJILERINDEKİ DOĞU ALGISI}

Açıklamacı ve anlamacı metottan hareket ederek Batılı düşünürlerin Doğu toplumlarını ele alırken edindikleri tavrın aslında bir tür Batı merkezlilikten ileri geldiğini belirtmek gerekir. Sunar'ın ifadeleri ile Batı'ın kendisini öteki olarak benimsediği Doğu üzerinden tanımlaması esas hatları ile Antik Yunan'a kadar götürülebilir. On sekizinci yüzyıl aydınlanma zihniyeti ile ortaya çıkmış olan yeni Batı toplumlarının da Doğu toplumları ile kıyaslanarak oluşturulduğu söylenebilir. Bu kıyaslamaların temelinde yatan ana etmenin, kilise otoritesi ile siyasi otoriteye karşı yapılan eleştirileri temellendirecek örneklerin Doğu illerinden (devletlerinden) verilmiş olduğunu gözlemlenmektedir (Sunar, 2012:105). On sekizinci yüzyılın sonunda ise kilisenin önemini kaybetmesi ve burjuvazinin üstünlüğünü ispatlamasıyla birlikte artık Doğu modeli aş1lan bir biçim olarak görülmeye başlamıştır. On dokuzuncu yüzyıl ise daha çok Doğu hakkında parçalı bilgiler elde eden seyyahların getir götürlerinden ziyade kapsamlı ve nitelikli çalışmaların yer aldığı dönem olmuştur (Sunar, 2011:31). 
Alman bilim adamlarının Doğuya karşı tutumu oryantalist bir tavır içerisinde gelişme göstermiş, yukarıdaki paragrafta belirtildiği haliyle, modern Batı toplumunun kendisini tanımladığı karşıt bir tasvir halini almıştır. Bu şekli ile şarkiyatçılık anlayışı kendi vazgeçilmez yerini Batı ve Alman toplumuna kabul ettirmiştir (Said, 1915:21). 1850 ve sonrasını takip eden süreçte ise bu şarkiyatçı anlayış kurumsal alanda da kendisini göstermiştir. Yüzyılın ikinci yarısına bakıldığında bu kurumsallaşma çalışmalarının daha da arttığı, üniversitelerde kurulan Doğu dil ve kültürlerine yönelik kürsülerin sayısının da arttığı görülecektir. Yani bu dönemde şarkiyatçılık kurumsallaşmış ve yerleşik akademik bilimler arasında yerini almıştır.1870 sonrasında ise emperyalist anlayışın desteğiyle şarkiyatçılık popüler kültüre dâhil edilmiştir. Batı zihniyetinin yeni kültür anlayışının üstünlüğünün bir göstergesi olarak literatürde yer almıştır (Bulut, 2002:117). Söz konusu olan bu sömürgecilik anlayışı resmen Avrupa'llların yeni bir iş alanını oluşturmuş, her ülke kendi çapında bir sömürgecilik zihniyetine bürünmüştür. Bu sömürge zihniyeti şarkiyatçı temeller üzerinden ilerletilmiş ve bu ülkeleri yarış içine sokmakla birlikte ayrıştırıp parçalamaktan ziyade tek bir payda da birleştirmiştir. Bu payda, Doğuya karşı Avrupalılık zihniyetinden meydana gelmiş̧tir (Holffbass, 2004:237-243).

Alman coğrafyasındaki gelişmeler dönemin en büyük popülerliği olan şarkiyatçı söylemler altında kendisini gerçekleştirmiştir. Bunlar gerçekleştirilirken de ekonomik alanda bir sömürgeciliği veya Şark tanımlamasından değil kültürel alanda din ve dil temelli bir şarkiyatçılık benimsenmiştir. Kapitalist olguda bu çerçevede varlığını göstermiştir. $\mathrm{Bu}$ anlamda Alman zihniyet dünyasının iki etkin düşünürü olan ve Sabri Fehmi Ülgener'in de analizlerinde yer verdiği ve etkilendiği ayrıca düşünceleri ile hala tartış1lan Marx ve Weber'in Doğu toplumlarının kapitalistleşmemesi hakkındaki düşüncelerini açıklamak gerekmektedir.

\subsection{Karl Marx ve Sosyolojisindeki Doğu Algısı}

Karl Marx, kendisini hayatı boyunca ve ölümünden sonra da hatırlatacak ve yeni ideolojileri de beraberinde getirmiş olan bir ideolojiyi bir düşünce sistemini oluşturmuştur. Bu düşünce sistemi, ekonomik temelli tarih algısına dayalı olan zihinsellik ve buna bağlı yaşam biçimini açıklayan ayrıca çözümünü de üreten çok yönlü bir sistem olan Marksizmdir. Bu anlamıla Marx sadece bir dönemin Almanyasına zimmet edilebilecek düşünür değil aynı zaman da Batının kapitalist anlayışının da temelini oluşturan ve sömürgeci sistemin karşısına koyduğu çatışmacı anlayışı ile günümüze kadar varlığını devam ettirebilmiş olan ve ettirecek olan iktisadi ve sosyolojik alanın baş ucu kitabı olma özelliğini koruyacaktır.

Marx'ın oluşturduğu bu düşünce sistemini onun yapıtlarında görmeye çalışıldığında karşımıza onun oluşturmuş olduğu tarihsel materyalizme dayalı (materyalizm ekseninde) ekonomik temelli bir insanlık tarihi çıkmıştır. Marx, "Seçme Yapıtları"nda da ele aldığı haliyle o insanlık tarihinin ilk başlangıç nedeninin yaşam olduğunu, daha sonrasında diğer doğayla ve insanlarla ilişkilerini sürdürdüklerini, tarih yazımında ise iklim, jeolojik, su, vd. özelliklerden ziyade mühim olanın ekonomik ilişkiler olduğunu vurgulamıştır (Marx-Engels, 2003:19). Mevcut yapıyı da Marx, tarihsel materyalizmden hareket ederek ve yaşadıklarından yola çıkarak meydana getirdiği analizlerinden hareketle ele almıştır. Bu haliyle de tarih olgusunu, genel ve özel anlamları ile Hegel'den ödünç aldığı diyalektik kavramı ile daimi bir akış içerisinde olan bir kavram olarak açıklamıştır. Tek farklılık ise tarihsel akışı sağlayacak olan yapının evrimsel değil devrimsel bir süreci, gücü içerisinde barındıran proleterya diktatörlügü ile mümkün kılacak olmasıdır (Turner, 2001:47). Bundan dolayı Marx'ın sosyolojisinde çatışma, olmazsa olmazlardandır. Bu anlamda devrime gidip, var oluşu evrensel çerçevede devam ettirecek olanda bu çatışmadır. Marx sosyolojisini karakterize ederken de bu çatışma ögesinden yola çıkmıştır. Çatışmadan uzaklaşan ve toplumsal süreci sürdürecek olan bu evrenin dışında kalan toplumları da Asya Tipi Üretim Tarzı kavramı ile tanımlamıştır. Marx, "Asya Tipi Üretim Tarzını" 1853'e doğru ortaya koymuştur ve hayatı boyuncada kullanmıştır (Godelier, 1993:13).

Marx edindiği felsefeden hareketle Asya Tarzı Üretim biçimini şu şekilde tanımlamıştır; Özel mülkiyetin yer almadığı, tarıma dayalı ve sulama işlerini düzene koymakla yükümlü, kalıplaşmış bir bürokrasi ve bir kast sistemi, ayrıca üretilen ürünün çoğuna el koyan merkezi, tek kişinin idaresinde dallanıp budaklanan, köklü bir devlet yapısı olarak ifade edilmektedir. Örnek olarak Mısır, Mezopotamya, Eski Çin ve Hindistan verilmiştir (Sezer, 1988:56). Bu toplumlardan ilk sırada olan Doğu toplumlarıdır. Bunun nedeni ise Doğu toplumlarının edindikleri devletçi yapıyla tek amaçları olan nesillerinin varlığını sürdürmek amacında olmalarıdır. İktidar değişiklikleri ise halktan uzak bir alanda kendi içerisindeki çatışmalar ile gerçekleşmektedir. Marx'ın felsefesinde de bu anlamıyla Doğu tarihsizlik içerisinde yer almaktadır. Sosyolojisini felsefe, iktisat, tarih ve biyoloji üzerine kuran düşünürün Doğu toplumlarını "tarihsizlik" ile tanımlaması da onun için ayrı bir anlam ifade etmiştir. Gerek Marx açısından, gerekse etkilendiği düşünürler açısından Asya Tipi Üretim Tarzına sahip 
toplumlar, Batının reel ve rasyonel dünyasının dışında yer alan topluluklar olarak kabul edilmiştir (Turner, 2001:19).

Marx'in oluşturduğu bu kuram var olan diğer kuramlardan farklı olarak, her türlü toplumsal görünüşü, toplumla doğa arasındaki ilişki bağlamında çözümlemekte ve insan toplumunu doğa dünyasına sıkıca yerleştirmektedir (Boottomore, 1990:135). Asya Tipi Üretim Tarzı Marx'a göre, ilkel topluluklardan sonraki aşamayı ifade etmektedir. Bu anlamda Batı medeniyeti topluluklarına Doğu toplulukları dahil edilemez. İslam medeniyetinden de bu anlamda bahsetmemektedir. Ayrıca, İslam kültür ve uygarlığının Batı medeniyeti ile Yunan toplumlarıyla arasında köprü görevi görmesini de görmezden gelir. Marx'da, ilkel topluluklardan Asya Tipi toplum yapısına geçmiş olan bu toplumlar bu evrenin ötesine geçirilmemişler ve burada adeta donup kalmışlardır (Godelier, 1993:16). Bundan dolayı tarihsizlikle nitelendirilmişlerdir.

Marx'ın bu anlatımları belirli bir noktadan sonra oryantalist bir biçim almıştır. Asya Tipi Üretim tarzı kendi içerisinde askeri bir yapıya dayanan ve halkın rıza gösterdiği kölelik (gönüllü kölelik biçiminde) üzerine kurulu bir yapıdır. Halkı yöneten ve ondan üstün olan güç her şeyin tek sahibidir. Tıpkı Tanrı'nın yeryüzündeki vekili gibidirler ve bu durum toplumsal alanda sınıfsız bir yapıya neden olmaktadır (Çelik, 2009:54). Bundan dolayı Marx sınıfsız bir toplumda çatışmanın olmayacağını ve sınıfsızlığın tarihsizliğe de neden olacağını vurgulamıştır. Aynı şekilde sınıfsız ve tarihsiz bir toplumun çatışma ile tanışmasının kapitalist aşamadan geçtikten sonra olacağını vurgular.Yani kapitalizmin ilkel yapısı, ehlilleşmemiş koşulları onlarda uyanışa neden olacaktır (Marx-Engels, 2003:408,414).

Sonuç olarak Marx'ın anlatılarından hareketle Doğu toplumları hakkında yaptığı çoğu açıklamanın eksik ve tutarsız olduğu tespit edilmiştir. Onun, Doğu toplumları ile ilgili hatalı olan anlatıları bir takım sorunlara da neden olmuştur. Örneğin kapitalizm içinde de çatışmalara neden olmuştur. Bundan dolayı olsa gerek, Stalin döneminde Asya Tipi Üretim Tarzı kavramı mahkûm edilmiştir. Ona göre; "ilkel dönem, kölelik, feodalizm, kapitalizm, sosyalizm ve kominizm" tüm dünya toplumlarının yapısını açıklamada yeterli görülmüş̧ür (Sezer, 1988:56). Netice itibari ile Marksizm, modernizmle ilişkisi yönünden; Batı'nın evren ve insan anlayışıyla, iç buhranıyla oluşturulmuş bir disiplin alanı olmaktadır. Bundan dolayı oluştuğu dönemin getirisi olan sömürgeci özellikleri de içinde barındırmaktadır. Bu anlamıyla Marx'ın Asya Tipi Üretim Tarzı oryantalist okumanın bir benzerini ifade etmektedir. Özellikle de devrimlerin yokluğu, olamayışı bunu ispatlar niteliktedir (Turner, 2001:118). Bu başlık altında Marx'ın ortaya koymuş olduğu sosyolojik analizlerine ve Doğuya ilişkin düşüncelerine değinildi. Bu konu üzerine yapılmış olan birçok eleştiri vardır. Ancak bunlar içerisinde en dikkat çekeni ve en çelişkili duruma sebep olanının sömürgeci bir toplum yapısını reddeden bir düşünürün Doğu toplumlarını sömürgeci bir sistemin uzantısı olan model etrafında tanımlamış olmasıdır.

\subsection{Max Weber ve Sosyolojisindeki Doğu Algısı}

Alman sosyologlarından olan ve ele alınan ikinci düşünür Weber'dir. Onun sahip olduğu sosyoloji anlayışını oluşturmada etkili olan kaynaklara bakıldığında Almanya'daki idealistik ve neo-idealistik düşünceyle birlikte Kant ve neo-Kantçıların izleri görülür (Kızılçelik, 1994:245). Büyük çoğunlukla Alman düşünürlerin etkisinde kalan Weber, metodolojisini de bu düşünürlerden esinlenerek belirlemiştir. Weber'in, Rickert ve Dilteyden yararlanarak elde ettiği ancak onlardan farklı biçimde görüp değerlendirdiği bu metoda "anlayış yöntemi veya anlamacı yöntem" denilmektedir (Kızılçelik, 1994:279). Anlayış yönteminin çıkış noktası esasen Weber'in etkilendiği aydınlanmacı düşüncedir. Aydınlanma felsefesine göre esas olanın "birey" olması Weber'in bireyi temel alan bir yöntem edinmesine katkıda bulunmuştur (Gert ve Mills, 1998:101). Ona göre sosyolojik ve kültürel alan ancak anlayış yöntemi ile ele alınmalıdır (Kızılçelik, 1994:279). Weber'in sosyolojisinde akla ilk gelen kavramlardan bir tanesi de ideal tip kavramıdır. Weber'e göre ideal tip kavramı, rasyonelliği esas edinen ve gerçekteki durumdan farklı olarak gerçekliği ifade etmeye yarayan bir tipoloji bir liderlik türüdür. İdea kavramının da bundan dolayı herhangi bir değer anlayışıyla alakası bulunmamıştır (Gert ve Milles, 1998:107).

Weber sosyolojik analizini yaparken Marx gibi ekonomi temelli bir okuma değil daha rasyonel olan ve sınırları daha kapsayıcı olan insan zihniyetinin daima ihtiyaç duyduğu din olgusundan hareket etmiştir. Din olgusunu ele alırken de dikkat ettiği husus bu olgunun nasıl mistik bir yapıdan uzaklaşıp ekonomik alana taşınması yani maddeleşmesi olmuştur. Buradan hareket ederek "asketizm" ve "kapitalizm" arasındaki ilişkiyi anlamaya çalışmış ve sorusuna cevap aramaya buradan başlamıştır. Asketizm, bir anlamda bireyi çile çekmeye iten, onu dünyada günahlarından arınması için çalışıp harcamayarak Tanrıya yükseleceğine inandıran düşüncedir. Yani bu dünya bir çilehanedir. Kapitalizm, özel mülkiyetin, üretim araçlarına sahip olunan arz talep ilişkisinin piyasa ekonomisi tarafından belirlendiği, sosyal ve ekonomik bir sistemdir. Kelime karşılığı ise sermayedir. Kapitalizm hususunda Weber, madde ile onu ortaya çıkaran ruh arasında fark olduğunu ortaya koymuştur. Weber'i diğer 
düşünürlerden ayıran nokta da bu olmuştur (Korkmaz, 2011:212). Kapitalist olguyu ortaya çıkaran şey ise insanların sahip oldukları dini inancı, yani Batı da asketizme Doğu toplumlarında ise mistisizme karşılık gelen, bu dünyayı boşlayıp kendini tamamen ibadete veren ve dünyevi arzu ve istekleri terk eden, her şeyi Tanrı'dan bekleyen anlayıştır. Bu anlayış reformlar yoluyla, zamanla maddeleşerek dünyaya açılmış, yani kapital sisteme alet olmuştur (Çaml1, 2013:22). Weber'in ifadeleriyle (Weber, 2006:188); "Reformasyon akılcı Hristiyan asketikliğini ve yaşam metodunu manastırdan alıp dünyevi meslek alanına taşımıştır". Bunu gerçekleştirme de burjuva sınıfınında rolünü unutmamıştır. Sonuç olarak dünyevi asketizmin sonu, Weber'e göre kapitalizmin ruhunu oluşturma noktasında bir kapı açmış ancak gösteriş, zenginlik ve ideal hayat algısı ile birleşen, para tutkusunun baştan çıkarıcılığı karşısında direnememiş ve modern dönemin kapitalist yaşam tarzına kendisini bırakmıştır (Weber, 2012:159).

Weber'in, Doğu dinlerini özellikle de İslam'ı ele alırken takındığı tavırda bu satırlardan hareketle oluşturulmuştur. Onun bu konu hakkında temel problem olarak gördüğü şeyse, kapitalizmin Batıdaki varlığı ve gelişimi ile Doğu toplumlarında kapitalizmin olamayışı ya da o toplumların kapitalistleşememesi durumudur. Bu problemi açıklığa kavuşturmaya çalıştığında en büyük yanılsaması ise kendi yöntemine sadık kalamamış olması ve bir kıyasa girerek, oryantalist bir tavır içerisinde açıklamalarını gerçekleştirmiş olmasıdır (Turner, 2001:72). Weber, İslam ile ilgili ifadelerinde İslam'1 Püritanizmin karşısına yerleştirmiş ve onu hazc1 bir anlayışla yorumlayarak, bu açıklamasına çok eşle evliliği örnek göstermiştir. Kadınlar, lüksler, mülkiyet anlayışı gibi konularda baskın olarak, yer verdiği hazcı sentezinde çileye veya çatışmaya yer olmadığını belirtmiştir. Bununla birlikte Kur'an'ın uzlaştırıcı etiği esas almasına ve ahlaki emirler ile dünya etiği arasında çatışma olmadığına da değinmiştir. Sonuç olarak dünya üstünlügüne dayalı, çileci bir ahlakın İslam'da ortaya çıkamayacağı anlamına geldiğini belirtmiştir (Kızılçelik, 1994:275).Yani üretmeyi önceleyen bir ekonomik sistemin İslam dininde olamayacağını vurgulamıştır. Tüm bu açıklamalarla Weber'in, Doğu toplumlarının kapitalistleşememesini açıklamada kullandığı bir diğer kavram "patrimonyalizm”'dir. Patrimonyalizm (Seyyar, 2007:744-745);

"Max Weber'e göre, geleneksel toplumlarda görülen ve yönetici erkek ile yönettiği ev halkl arasindaki iktidar ve itaat iliş̧isinin keyfi bir şekilde, değiş̧ikliğe uğramadan ortaya çıkan, siyasi alana yansımış olan halidir. Kavramın vasıflart ise otorite (hanedan ailesinin kullandiğl şahsi ve bürokratik güce dayalıdır), keyfi bir hükmediş hâkimdir, yasama, yürütme ve yargı tek elde toplanır, halk mevcut yapıya sadakat göstermek zorundadır, meşruluk bu şekilde sağlanır"

şeklindedir. Weber'in bu ifadeleri onun bu açıklamalarının, kendi düşünce dünyasında bir tür gerici zihniyete karşılık geldiğini göstermiştir. Fakat Weber'in bu açıklamalarının dayanağına bakıldığında onun "Ekonomi ve Toplum" adlı eserinde ki açıklamalarından anlaşılacağı üzere daha çok Müslümanların hicret öncesi dönemlere ait olduğu fark edilmektedir (Turner, 1997:66).

Weber'e göre patrimonyalizm, otoritesini gerçekleştirmek için memurlara ihtiyaç duyan, tek kişinin yönetimidir. Patrimonyalizm evresinden sonra yönetim tamamen keyfi bir hal almıştır. Bu keyfiliğin Weber, yönetilen sınıftan değil sultanın iradesinden kaynaklandığını belirtmiştir (Turner,1997:147). İktidar ve maaşlı memurlardan ibaret olan patrimonyalizm de hukuk anlayışı, gelenekler ve dini kurallar üzerine inşa edilmiştir (Turner, 1997:196). Weber, Doğu toplumlarını kadınlara karşı tutumlarından dolayı bir de özerk şehirlerin bulunmamasından dolayı eleştirmiştir. $\mathrm{Bu}$ şehirlerin gelişmeme sebebi olarak Weber, savaşçı bir İslam anlayışını ve patrimonyal anlayışın bu yapıyla bütünleşmesini gerekçe olarak gösterir (Turner, 1997:177).

Sonuç itibariyle Weber, İslam'ın ilk defa ortaya çıkmasından itibaren toplumu dönüştürmeyi başaramadığını, tam tersine kendisini toplumun o bozuk yapısıyla özdeştirdiğini ve bununda zamanla sert bir askeri yapıyla birlikte patrimonyalizmi doğurduğunu, patrimonyal yapının da devleti aşkıncı bir yapıya taşıdığını vurgulamıştır. Ayrıca bunun gücü elinde bulunduran sultanlara Tanrısal nitelik kazandırdığını, en sonunda da bu yapının kapitalizmle örtüşmediğini, kapitalizmin Doğu toplumlarında yer edinmesine mani olduğunu belirtmektedir.

\subsection{Sabri Fehmi Ülgener ve Sosyolojisindeki Doğu AlgıSı}

\subsection{1. İktisadi Analizde Yer Alan Kavramlar}

$\mathrm{Bu}$ başlık altında temel olarak kapitalizmin sosyolojik temellerini açıklamak konusunda Sabri Fehmi Ülgener tarafından oluşturulmuş olan iktisat ahlakı, iktisat zihniyeti ve dönemin zihniyet sorunu olarak da ele alınan ve kapitalistleşmenin önünde engel olarak görülen fütüvvet ve tasavvuf anlayışına yer verilecektir. 


\subsubsection{1. İktisat Ahlakı}

Ülgener, iktisadi gelenek içerisindeki kapitalistleşememe olgusunu ele alırken iktisat ahlakı ile iktisat zihniyetini birbirinden ayırarak ele almayı tercih etmiş ve bu her iki alanın kendi içerisinde bir değerlendirmesini yapmıştır. Daha somut ve tasvir edilebilir olan iktisat ahlakı Ülgener'in tanımıla; "Iktisat ahlakl, gündelik tavir ve davranışlarımız üzerine - doğrudur veya ĕgridir yollu- yargılayıcı değer hükümlerinin söz ve deyim halinde ifadelendirilmiş bütünüdür”. Burada "doğru ve e ğri” tabirini Ülgener, tanımın içinde barındırdı̆̆ normatif taraf olduğunu, yine "söz ve deyim halinde" ifadesinin de ahlak anlayışının kapalı bir özellikte değil tam tersine açık bir şekilde ve kendi dönemininde ötesine geçebilme özelliğine sahip olduğunu belirtir (Ülgener, 2006a:19).

Yine Ülgener iktisat ahlakını dini anlamında da ele almış ve kavramı, bireyin dini yükümlülüğü çerçevesinde sergilemiş olduğu davranışların toplu bir ifadesi olarak tanımlamıştır. İktisat ahlakı, bir taraftan züht ve riyazete insanı çekerken diğer taraftan da mal ve mülk ile sürekli haşır neşir olmayı ve sonuçta iki nokta arasında orta noktayı bulma çabası olarak tanımlanmıştır (Ülgener, 2006a:20). Bir üçüncü tanıma göre iktisat ahlakı (Ülgener, 2006a:20); “...diğer taraftan belli bir çă̆ın (veya çevrenin) ahlak anlaylşı olarak bir mana taşıyacaksa, değer ölçüleri ile tek ve dağınık grupları değil, geniş ve yaygın bir çevreyi muhatap alması gerekir” şeklindedir.

Yapılan bu iktisat ahlakı tanımlamalarından kavramla ilgili çıkarılabilecek sonuçlar şu şekildedir. Öncelikle bir sonuçta iktisat ahlakının dar bir grup ya da çevre etrafında değil daha geniş bir çevreye, tabana hitap etmesi gerektiğidir. İkincisi iktisat ahlakı belirli kurallar çerçevesinde gelişen bir alan değildir ayrıca sadece din âlimlerinin görüş ve kararlarının da bir ürünü değildir. Tamamen insanların günlük yaşayışında elde ettikleri değer ve tercihlerinin oluşturmuş olduğu motifler ve telkin toplamıdır (Ülgener, 2006a:20-21).

İktisat ahlakını etkileyen unsurlara bakıldığında bunların ilk başında çevre, ekonomik yapı gibi değişkenlerden ziyade din gelmektedir. İktisat ahlakının oluşumunda dinin rolünü Ülgener şu şekilde ifade etmiştir; “...Ahlak sistemini kuran ve yöneten fikir devrin karakteri icabı din ve ilahiyattır” (Ülgener, 1981:52). Ülgener, dinin iktisat ahlakı üzerindeki etkisini bir tür mesafe bilinci anlayışından hareketle anlatmıştır. Mesafe bilinci, insanın ihtiyaçlarına göre madde, çevre ve zaman ile içten dişa doğru kurduğu ilişkiyi ifade eder (Ülgener, 2006a:31).

Ülgener'in dinin iktisat ahlakının oluşumuna etkisi konusunda ele aldığg bir diğer husus taban ve tavan ilişkisidir. Buradaki taban ve tavan olgusu Marx'ın alt ve üst sınıfın oluşumunda etkili olan ekonominin ötesinde dinin etkisinin daha etkin olduğunu gösterir niteliktedir. Burada yer alan taban ve tavan arasındaki farklılığın nedeni ise insanların dini olguları yaşama, anlama ve algılama farklılığından ileri gelir. Bu manada tavan, dini maddeden arınarak yaşayabilen, nefsini terbiye edebilmiş ve ilerlemeye çalışan bir nevi dini alanın elit kesimini ifade etmiştir. Örnek olarak, İslamiyet'te din mücahitleri ve tasavvuf uluları, şeyhler, Hristiyanlık'ta keşiş, Kalvinizmin sert riyazetçisi, vb. şeklindedir. Taban ise tavana göre daha çok dünya kokan ve dinin gereklerini tam olarak idrak edememiş kesimdir. Bu nedenle taban ile tavanın dini yaşayışı ve uygulayışı farklı olacaktır. Bu farklılık temel de bir farklılı̆g beraberinde getirmese de zamanla bir tür ikiliğe neden olmuştur. Bu ikilik evresine ise İslamiyet'in tasavvuf evresinde rastlanır (Ülgener, 2006a:38-40).

Taban ve tavan arasındaki ilişki mistik dinler ile riyazete dayalı dinler arasında farklılık göstermektedir. Mistik din anlayışında tavan ile taban arasındaki uçurum belirgindir ve kolay bir şekilde kapatılamamaktadır. Riyazete dayalı dinler de ise taban ve tavan arasındaki ikilem ortadan kalkabilmektedir. Mistik dinlerde hem dünya ile hem de çevre ile ilişki kurmak mümkün değilken, riyazete dayalı dinlerde dünyevi yaşam ile dini yaşam arasında da bir bağ kurulabilmektedir. Mistik din anlayışının hakim olduğu coğrafyada ekonomik alanda da ikilemler yaşanabilmektedir. Bunun en bilinen örneği İslam kültürü ve edebiyatında yer alan "rint ve zahid" çatışmasıdır. Bir tarafta dünyayı reddedip bir kendi iç huzuruna kapılıp koyu vermişlik (rind) ve diğer tarafta da kendini biçime kaptırıp iç duygularını (batın) unutmuş bir (zahid) (Ülgener, 2006a:35-36). Bu konuda Asya ve batı toplumlarını karşılaştıran bir açıklamaya yer vermek gerekirse (Weber, 2006'dan akt.: Ülgener, 2006a:42$52)$;

"Tarih açısından çoğunlukla Asya dinleri ile batı dinleri arasında ki önemli fark, birincilerin içe dönük bir huzur ve teslimiyete, ikincilerinin ise riyazete doğru yol almış olmasıdır. Farklar şüphesiz kesin değildir... mistik ve riyazetçi unsurların... Bizim için önemli olan, söz konusu karışım içerisinde hangilerinin zamanla ă̆ırlık kazanmış olacağının tespitidir. Bu gözle bakınca, batının değer kompleksinde riyazet yoluyla gide gide aktif bir iş ve çalışma idealinin öbürleri önüne geçirildiği ve pratiğe aktarıldı̆̆ gözden kaçmayacaktır".

$\mathrm{Bu}$ anlamda riyazete dayalı dinlerde ekonomik alanda da ilerleme olmuş ve "kapitalizm" de oralarda bilinçli bir şekilde olmasa da ortaya çıkmıştır. 


\subsubsection{2. İktisat Zihniyeti}

Zihniyet olgusunu genel anlamda ele aldığımızda tam bir tanımlamaya giremeyecek kadar geniş bir kavramdır. Bu nedenle ayrıntıya girmeden kavramsal düzeyde bir açıklama yapacak olur isek, öncelikle "bilinç" veya "bakış açısı" şeklinde ifade bulan "zihniyet" zihin kavramından türeye gelmiştir. Zihin ise genellikle değerlendirme, düşünme, anlama, anımsama ve karar verme de işe yarayan yeteneklerdir. Zihniyet kavramının zihinden ayrılan kıstası ise zihniyetin sadece salt bilgiden değil toplumsal bir takım bağlantılara da sahip bir kavram olmasındandır (Aydın, 1997:124). Ülgener de zihniyet olgusunu incelerken onu zihniyet ahlakından ayrı tutarak açıklamaya çalışmıştır. Ancak bunu yaparken de her iki kavram arasındaki kesin bir ayrımdan da bahsedilemeyeceğini söylemiş ve bunun nedenlerini de şu şekilde açıklamıştır (Ülgener, 1983:19); "İktisat süje ve süjelerinin... Bir bakıma genelde hepsi de belli bir bakış açısında bütünleşmiş haliyle sürdürülen değer hükümleri, tercih ve eğilimler toplamı! Daha kısası: dünyaya ve dünya ilişkilerine içten dışa doğru bir tavır alış". Yani Ülgener'e göre zihniyet insanın sezgilerine bağlı olarak anlamlandırdığ 1 şekilde davranış sergilemektir. Bir örnekle açıklamak gerekirse modern ve geleneksel kültürde zaman kavramına insanların yüklediği anlam verilebilir. Geleneksel kültüre sahip olan kişi "kazan-kazan" yarışının ya da kapitalist olgunun daha çok dışında kaldığı için işlerinde zaman ile ilgili takınacağı tavır "acele işe şeytan karışır" şeklindedir. Modernizmi tanıyıp onun içerisinde oluşmuş olan bir zihniyetin ise zaman kavramına karşı tutumu "vakit nakittir" şeklinde olacaktır (Ülgener, 1983:19).

Zihniyet kavramının karıştırıldığı veya onunla özdeşmiş gibi kullanılan kavramlara baktığımızda ise karşımıza kültür ve ideoloji kavramı çıkmaktadır. Özellikle de kültür ile aynı şeymiş gibi algılanan zihniyet ondan farklıdır (Özönder, 1987:291). Bu yanılsamanın temel nedeni kültür ve zihniyetin etkilendiği unsurların benzer olmasından kaynaklanmaktadır. Bu anlamda da iki kavram arasında bir aynılık değil bir tür kesişme söz konusudur (Ülgener, 1983:23). İdeoloji konusunda ise Ülgener (Ülgener, 1983:98);

\section{"İdeoloji, belli bir toplum kesiminin (grup, sinıf, mezhep, meslek, vs. mensuplarının) - statüleri ile uyum halinde ve yerine göre davranışlarını haklı ve meşru göstermek üzere- paylaştıkları ortak düşüncelere, mithos 'lar ve değer yargıları toplamıdır.}

Tanımdan da anlaşılacağı üzere ideoloji tek bir bireyin değil toplu bir anlayış ve kavrayışın özelliğidir. Ülgener'e göre (Ülgener, 1983:98); “yalnız düşünce katında oluşan ve orada kalan bir zihin oyunu, bir düşüntü gibi değil, onların söz ve yazı halinde dışa vuran tarafıdır”. Bu anlamda ideoloji kavramında da yine bir tür kesişme söz konusudur. Bu kesişmenin nedeni ise ideoloji olgusunun da bir takım olayları ifade etmek için kullanılmasından ve bilimselmiş gibi gösterilmesinden kaynaklandığı söyleyebilir. Bu durumda ortaya çıkan şey o ideolojinin temelinde bulunan bir bilimsel argümandan değil tamamen kavram üzerine başkaları tarafından atfedilen bir değerin ürünü olmasından kaynaklanmaktadır. Netice itibariyle zihniyet ve ideolojinin dolaylı yoldan benzerlikleri veya kesişimleri, iki kavramında algılanan bir takım düşüncelerin ve bunların değerlendirilmesinin sonucu dışarıya yansıtılabilen yönü olmasından kaynaklanmıştır. Ancak zihniyetin ideolojiden farklı olarak bilimsel temellere sahip olduğu unutulmamalıdır.

\subsubsection{3. İktisadi Ahlakı ve İktisadi Zihniyet Arasındaki Farklar}

İktisat zihniyeti ve iktisat ahlakı kendi içlerinde anlaşılması güç olan ve hangisinin hangisi üzerine yerleştirildiği belli olmayan kavramlardır. Bu muğlaklığg gidermek ve kavramları daha anlaşılır hale getirmek için iki kavram arasındaki farklara değinmek gerekir. Ülgener'e göre iktisadi zihniyet, tamamen içten kaynaklanan, içten gelen fiil ve hareketlerimizin ortaya çıkmasını sağlayan görünmeyen taraftır. İktisat ahlakı ise davranışlarımızın kendisi veya karşılığıdır. Yani meydana gelen, görünen kısımdır (Ülgener, 2006b:17). Yine Ülgener, "İktisadi Inhitat Tarihimizin Ahlak ve Zihniyet Meseleleri" adlı eserinde iktisat ahlakını "uyulması istenen hareket ve normların kurallarının toplam ifadesi" olarak tanımlarken iktisadi zihniyeti ise "gerçek davranışında kişinin sürdürdüğ̈̈ inançların ve değer toplamının" olduğunu belirtmektedir. Netice olarak Ülgener farklılığg ş̧ şekilde ortaya koyar; "iktisat ahlakı, toplumda uyulması istenen normların, davranışlarının ve hareketlerin tamamı veya toplam ifadesi iken; iktisat zihniyeti de, bireyin gerçek davranışında sürdürmüş olduğu inançların ve değerlerin bütünüdür" (Şimşek, 2007:209).

\subsubsection{Fütüvvet ve Tasavvuf}

Ülgener, Doğu ülkelerindeki zihniyet oluşumunda tasavvuf ve fütüvvet anlayışını da önemli bir etkileyici faktör olarak görmüş̧ür. Çünkü bu faktörlerin halkın icrası olan her işin oluşumunda tesiri olduğunu düşünmektedir. Bu nedenle iki kavramı ayrıntılı olarak ele almış ve İslam ile ilgili ilişkisini de açıklamaya çalışmıştır. 
Ülgener tasavvuf anlayışını açıklama da şu ifadelerden faydalanmıştır; Tasavvuf, “... yerden bitercesine üretip peşine taktığı tarikatlarla beraber 12. ve 13. yüzylllardan bu yana Anadolu insanının çilesi ile içli dışlı olmuş! Moğol istilalarının, ardı arkası kesilmeyen sürgün ve baskınların yerinden yurdundan ettiği perişan kütleler karşısında bir huzur ve güven köşesi..." (Ülgener, 1981:73) olarak kabul edilmiştir. Böylece Ülgener, Doğunun zihniyetini etkileyen tasavvuf anlayışının sade bir İslam anlayışından değil, çeşitli etkileşimler sonucu oluşan tasavvufi tutumlardan ibaret olduğunu göstermiştir. Bununla birlikte tasavvuf anlayışı toplumsal katmanlaşmanın ekonomik boyutunun dışında ayrıca dini-kültürel alanda da tabakalaşmayı beraberinde getirmektedir (şeyh-mürid ilişkisi).

Doğu toplumlarında tasavvuf anlayışı tek koldan değil çift koldan ilerlemiştir. Bu kollarda birbirinin tam zıttıdır. Bunlardan bir tanesi Batınilik diğeri ise Melamiliktir. Batınilik daha çok dünyayı değersiz ve üzerine bir çivi çakmaya dahi gerek duymayacak kadar görmezden gelen, bu dünyanın geçici (yalan, fani) olduğunu ve bunun için uğraşmamak gerektiğini benimseyen, tamamen mistisizme kapılmış olan bir anlayış ve dünyayı boş vermişliği yaşam biçimi haline getirmiş olan, bir dünya görüşüdür (Sayar, 2006). Batıniliğe tepki olarak ortaya çıkan ve onun yıkıcı etkilerini ortadan kaldırmak için oluş̧urulan diğer bir anlayış ve tasavvufi alanın ikinci kolunu oluşturan Melamiliktir. Ülgener'e göre Melamilik (Ülgener, 2006a:103);

"Melami Hakk'a yakınlı̆̆ını halkın dışında belli bir davranış ve özel klyafetle sergilemeyi asla düşünmeyerek, herkesle beraber ve herkes gibi işi gücü peşinde; kulluğunu ise arada sessiz sedasız yerine getirmekle meşgul! Daha kisası: Görünürde halkla, gönülde Hakk'la beraber! Sade ve son derece gösterişsiz yaşantısı içinde çalışma ve üretmenin- Kalvinist çizgiden geri kalmayan- ısrarlı takipçisi! Klyaslama, istenirse daha da ileri götürülebilir: Melami Tanrl varliğında benliğini ifna etmeyi gaye olarak muhafaza ile birlikte, irade ve hareket tarafina yine de bir çıklş ve boşalma firsatı arayıp bulmayı elden bırakmamıştır. Kendi başına belki bir "hiç"; fakat bütün o hiçliği ile emanet aldı̆̆ Tanrı kudretinin taşıyıcısı ve aleti olarak "var" oluşun tam ve eksiksiz bilincine sahip!",

şahsiyettir. Melamiliğin en güzel temsilciliğini Hacı Bayram Veli tarafindan kurulan ve başını yine Hacı Bayram Velinin çektiği Bayramiyye tarikatı oluşturmaktadır. Hacı Bayram Veli'nin Melamilik ve Ahilik anlayışına yakınlığını ise onun geçinmek için kendi el emeğiyle bir çiftlik kurup orada çalışması ve birçok müridine de iş sahibi olmayı önermesi göstermektedir (Yılmaz, 2004:265). Ülgener'e göre dünya, zevk ve haz tarafları benimsenmemesi gereken bir şeyken maddi olarakta işlenmesi, biçim verilmesi, bir düzeni gerektiren madde yığınıdır. Bu nedenle dünyanın zevkine kapılmamak gerektiğini madde yönünden de ondan tamamen soyutlanmamak gerektiğini vurgulamaktadır (Ülgener, 2006a:102). Yine Ülgener'e göre çalışmak, müminin en temel vazifelerinden biri olarak anlatılır (Ülgener, 2006a:106-107). Benzer ifadeyi Nur suresi 37. Ayette onaylar. Ayette, "O kişiler ki ticaret ve alım satım Allah'l anmaktan kendilerini alıkoymaz”, hükmüne yer verilmiştir. Ülgener, Melamiliği Batıniliğin karşısına, Batıniliğe bir karşı koyuş olarak ve onu Anadolu'da Kalvinizmin yansıması olarak çıkarmıştır (Zorlu, 2006:191).

Fütüvvet boyutuna bakıldığında ise kavramın tasavvufi öğretinin esnaf ve zanaatkar toplumda oluşturulan ahi teşkilatlanması ile bir tarikat halini almış görünümü olduğunu belirtmek gerekir. Fütüvvetnameler ise bu tarikatların ahlak kurallarının yazılı halde kaydedildiği şeklidir (Ülgener, 1981:89). Bir başka husus ise fütüvvet ve tasavvuf anlayışlarının her dönem iç içe olduğunu söylemenin yanlış olduğudur. Fütüvvetin ilk dönemlerine bakıldığında karşımıza insanların zulüm görenlere sahip çıkması, cesaret ve yiğitlik, el açıklığı, cömertlik gibi Batıdaki şövalyelik anlayışına benzer bir görüntü çıkmaktadır (Demirpolat ve Akça, 2004:356). Ancak daha sonra tasavvufun da etkisi ile Ülgener'e göre esnaf ve zanaatkârlardan meydana gelen fütüvvetlerin dinamik, dışa dönük ve daha atak, daha iddialı yapısı pasif, içine kapanan, hesabını da muhafazakâr ölçütlere göre yapan yapıya dönüşmüşlerdir. Ülgener'e göre bu durumun nedeni pazarların küçülmesi, artan siyasi istikrarsızlık, istilaların artması ve zorunlu göçler gibi benzer durumlardır. Bu durum karşısında toplum çareyi tasavvufun sabır ve güven anlayışında, tekkelerin hiyerarşik düzeninin sağladığı birlik ve bütünlügünde, güven atmosferinde teselli bulmaya çalışmışlardır (Demirpolat ve Akça, 2004:362).

Bu durumun sonucu olan fütüvvet anlayışını Ülgener şu şekilde ifade etmiştir (Ülgener, 1941:368); “küçük burjuvazi tekke duvarları arasında hayat bulmuş ve yenilikçi, atılgan, gözü pek, dünyaya ve maddeye açık, hüviyetlerinden slyrılmış, teslimiyetçi, itaatkâr ve maddeye karşı mesafeli bir kütle esnafi" profilini ortaya koymuştur. Sonuç olarak da ahilik, yarınından endişe duymayan, küçük, planlamanın saçma olduğunu kabul eden, rızkından emin, rasyonellikten uzak, pirinin sözünden ayrılmayan, himmet ve nimeti aynı kapıda arayan ve bu kapıdan ayrılmanın sonunun pişmanlık olacağını düşünen anlayışa sahip bir iş hayatını ifade eder olmuştur. 
Tasavvuf konusunda dikkat çeken noktalardan bir tanesi toplumun tasavvuf anlayışının çok çalışıp dünya hevesine kapılmayın sözünü üretim konusunda yerine getirmelerine rağmen, tüketim hususunda tam tersini yapmış olmalarıdır. Ülgener mutasavvıflarda görüldüğünü savunduğu bu yaklaşımın nedenini üç şeye bağlamıştır. İlki tasavvuf kesimindeki iki yüzlülük, yozlaşmışlı ve ortaya koydukları değerlere sadakatsizliktir. Diğer bir sebepse bu kesimin yükselmek, mevki ve tüketim için tasavvufu bir araç olarak kullanmalarıdır. Çünkü dikey ve yatay hareketliliğin kısıtlı olduğu toplumlarda soy itibariyle önemli bir yerde olmayanların yükselme yöntemleri bilim diğeri ise tasavvuftur (Ülgener, 2006a:126-127). Üçüncü ve en önemlisi tasavvuf ahlakında en üst mertebeye ulaşmış olanların dünya ile alakadar olmalarında bir sakınca görülmüyor olmasıdır. Yine Ülgener'e göre Batı toplumlarının reform ile yok ettiği ruhban sınıfını Doğu toplumlarında ortaya çıkaran ve İslam anlayışına tavan ve taban ayrımını getiren de tasavvuf anlayışıdır (Ülgener, 2006a:135).

Ülgener'in ideal tiplerinden biri olan ortaçağ anlayışının ve kültürünün oluşumunda etkili olan da yine ona göre tasavvuf anlayışıdır. Çünkü bu çağın temel karektaristiğinde tüketim toplumu anlayışının yattığını vurgulamıştır (Ülgener, 2006a:196). Ortaçağlaşmanın oluşmasından bahsederken Ülgener, sadece tasavvuf anlayışını sorumlu tutmasa da bu anlayışını meşru hale getirir (Zorlu, 2006:192). Son olarak tasavvuf anlayışının tavana yükselmek isteyenler tarafından, feodal sistemin içinde yer etmek isteyenler ve kendilerinin geçimini sağlamak için gerekli olan iş gücünü ve maddi yükü tabana yüklemek isteyenler tarafından da kullanıldığına değinmiştir. (Ülgener, 2006a:136). Ülgener tasavvuf anlayışını ele alırken tüm tasavvuf ehli hakkında genelleme yapmamış ve saf bir niyet ile bu yola çıkmış olanları ayrı tutmuştur.

\title{
4. KAPİTALIZMIN SOSYOLOJIK TEMELLERİ KONUSUNDA SABRİ FEHMİ ÜLGENER ODAKLI ELEŞTIRILER
}

\section{1. Ülgener'in Marx ve Weber ile İlgili Eleştirileri}

Bu bölümde Ülgener'in Marksizme ve Weber'e yaptığı eleştirileri ele alınacaktır. Ancak Ülgener'in Marx'a yönelik doğrudan bir eleştirisi olmadığı için bu konudaki eleştirileri daha çok Marksizm ve onun Türkiye'deki yansımaları üzerinden ilerletilecektir. Ülgener'in bilimsel alana karşı tutumu genel olarak edindiği tarafsızlı üzerine yoğunlaştığı için burada da yine herhangi bir şekilde tek bir tarafın savunuculuğunu yapmamış ve nesnelliğe hayli dikkat etmiştir. Bundan dolayı kendisi dönemin Marksist söylemlerine de katılmamıştır. Bu sebeple onun buradaki eleştirileri birkaç noktayla sınırlıdır.

Öncelikle Ülgener, Marksizmi aydın kesimin anti-kapitalizme yatkın olmalarını sağladığı için eleştirmiştir. Bununla birlikte aydın kesimin Marksist ideolojinin entelektüel tarafına kapılıp halktan uzaklaşmalarına sebep olduğu ve politika ve sokağı üniversiteye taşıdığı için eleştirmiştir. Ülgener bunu Röpke'den yaptı̆̆ ş̧u alıntılarla ifade etmiştir (Ülgener, 1983:95-96);

\begin{abstract}
"hiçbir ilim bourgeois ilmi yahut proleterya ilmi olamaz ve yine hiçbir ilim ulusa yarar olamaz. Yani ulusa yarar olsun diye gerçek olmayan şeyleri söylemeye mecbur tutulamaz. İlim adamını cebretmekle hiçbir zaman ulusun menfaatine hizmet edilmiş olmaz; bilakis ilmin zedelenmesi ulusun ziyaninadır. Yaşamasına gereken havası olmayan, hürriyet ve kudreti alınan ilmin ăgacından pratik yemişleri almak mümkün değildir. İlmin doğrudan doğruya bize, sinıfimıza, ulusumuza faydalı olmasını beklemek onu anlamamak demektir; aynı şey sanat ve din içinde böyledir".
\end{abstract}

Kemalizm'e de bu anlamda hiç destek vermemiştir. Ülgener'in, Marksizm'e ve onun Türkiye'de uzantısı kabul edilen Kemalizmi eleştirme ve ilgi duymama nedeninden bir diğeri onun yöntemsel tutarlılığını zedelemek istememesidir. Çünkü anlamacı yöntem insana önem vermekte ve bireyi önemsemektedir. Marksizm, materyalist anlayışı içinde barındıran ve tarih anlayışını da bu anlamda ele almakta olan bir ideolojidir. Ülgener ise yukarıda ki açıklamalarımızda da bahsettiğimiz haliyle tarihsel okumayı insan-insan yaklaşımından yola çıkarak açıklamaktadır. Yani Ülgener' in zihniyet algısı Marksizm'e uymamaktadır. Ülgener'in Marksizm'e mesafeli olma nedeni olarak kendisinin olayları açıklamada bir nedensellik algısı içerisinde olması gösterilebilir. Çünkü Marksizm, nedensellikten hareket ederek değil bunun yerine diyalektik materyalizm ile olayları ve olguları maddesel olarak açıklar.

Ülgener'in Weber'i eleştirdiği noktalara gelindiğinde ilk ve en önemlisi, Weber'in İslam'a karşı katı tutumunu eleştirmesidir. Ona göre bu düşünceler aceleci bir oryantalistin ifadeleridir (Ülgener, 2006a:56). Ülgener mevcut durumu şu şekilde izah eder (Ülgener, 2006a:58); 


\begin{abstract}
"Nerede ne vakit İslam'dan söz edilse çizilen tablo hareketsizdir. Kâh ilk ve öz kaynaklardan devşirme, kâh yüzyıllar sonrasının derviş cezbesinden aktarma, fakat her defasında Batı'dakine yüzde yüz ters olmasina dikkat edilerek seçilmiş inançların basit, tek katl bir kesit üzerine resmedilişi! Birinden öbürüne geçiş, bir kutuptan diğerine kayma; zıt alternatifler arasında ileri geri oynamalar; ve nihayet değerler sisteminin yavaş kararlı biçimde bir tarafa bel verişi... Hayır bütün bunların hiçbirini Weber de bulabilecek değiliz. Ve daha garibi: Mukayesenin bir ucuna Hristiyanlı̆̆ın ne olsa belli bir tarih kesiminde (reformasyon sonrasi) kanatlarından biri Kalvinizm ve ona yakın meshep ve tarikatlar-oturtulurken, karşı uca kontrast'l diye neredeyse tarih dışına sürülmüş bir İslam imajı getirilip oturtulmuş! Biri kaba hatlartyla ile de olsa başı sonu bilinen bir tarih diliminde ve az çok belli bir bölge içinde; öbürü başı sonu olmayan yaygın, belirsiz bir platform üzerinde!".
\end{abstract}

Weber'e göre İslam toplumsal yapısı göz önüne alındığında tamamen fütuhata ve cihata yönelik bir din ola gelmektedir (Kurt, 2010:6). Bununla birlikte İslam'ın alanının genişlemesini sağlayan da savaş̧̧ılar olmuştur (Özkiraz, 2003:51). Dinin çok kısa bir süre için cihat yoluyla yayılmasının ardından İslam topluluklarının dayandıkları nokta tarikatlardır (Ülgener, 2006a:59). Weber'e göre sadece anımsatmaktadır. İslam toplumunda zengin kesimin gelirini savaş ganimetlerinden elde etmiş olması İslam'ın sosyal ve iktisadi yapısının feodalizme benzetilmesine neden olmuştur. Weber'e göre kaynağ 1 üretim ve ticaretten daha fazla savaşa dayalı olan bu gelirlerin gerektiği kadarı tüketilip gerisi üretimin devamlılığını sağlamak için kullanılmamaktadır. Bunun yerine daha çok iyi bir yaşam sürmek ve toplumda statü edinmek için kullanılmaktadır (Türkdoğan, 2005:28). Bu anlamda İslam, Weber açısından Kalvinizmin karşısında yer alan bir olgudur. İslam toplumu, ferdi, feodal ve savaşçı, aristokratik ilişkilerin sürdürüldüğü bir topluluğun içinde yer alarak tüketim ekonomisi başlığı altında yer almıştır. Yani kısaca İslam, Kalvinizmin ideal tipi olan ve sürekli birikim yapıp değer oluşturan anlayışın zittı olarak sunulmuştur. (Kurt, 2010:7).

Weber, Marsistlerin Hıristiyanlığı tek bir yönüyle eleştirmelerine karşı çıkmasına rağmen kendisi de İslamı tek taraflı olarak eleştirmiştir (Turner, 1997:53). Weber'in İslam'ın sosyal hayatında ve iktisadi ahlakında da etkili olan diğer gruplara yer vermeyerek onu değerlendirmesi, onun yöntemsel tutarsızlığını ve idea anlayışından kaynaklanan yanılsamaları ile ifade edilmektedir. Çünkü Weber, olması gerekende kalarak olanı görmezden gelmiştir (Çelik, 2003:663). Weber'in İslam toplumlarını üretimden ziyade bir tüketim toplumu olarak tanımlamasında ve Kalvinist harekete benzer bir olgunun olmadığı iddiasında yanılmıştır. İlk olarak daha önceki bölümde bahsettiğimiz Melamilik anlayışı Doğu'da Kalvenizm'in bir karşılığıdır. Çünkü Melamilik tarikatı da dünya ile kurduğu bağda Kalvinist görüşle örtüşmektedir. Onlarda dünyaya içten bağlanmamakta ama dünyay1 biçimlendirilmesi gereken bir alan olarak görmektedirler. Bu noktada ikinci önemli örneğimize Rodinson'u tanık göstererek devam etmek gerekirse, İslam'ın Protestanları kabul edilen Mozab'lılardan bahsetmek gerekir. Çünkü Rodinson, Weber'in İslam ve Hint topluluklarını yani Doğuyu kapitalistleşememekle suçlamasına karşı ilk kapitalist hareketlerin buralar da başladığını ancak sömürgeci bir sistem içerisinde bunu gerçekleştiremediklerini vurgulamıştır (Rodinson, 1996:219; Veysal, 2010:267).

Yine Rodinson Weber'in nedensellik çemberi içerisinde ilerleyerek gerçek anlamda var olanları göremediğini, Doğu toplumlarının kapitalistleşememesini İslam kültüründe şehre özgü zanaatkar dindar anlayışının olmaması ve özerk şehrin oluşturulamamasına bağlamasının hatalı olduğunu ve onun ideaların yanılsamalarına düştüğünü göstermeye çalışmıştır. İslam'ın kapitalizme en yatkın din olduğunu ispatlamak amacıyla da Mozaibleri örnek verir. Cezayir'in güneyindeki vaha da yaşayan Mozab'lllar, Abadites'lerin Müslüman kolundandırlar. Mozaibliler çölde bir taraftan hurma yetiştirmişler diğer taraftan da ticaret yapmaktadırlar. Cezayir ve dışında mal alıp satmışlar ve faizle ödünç vererek büyük bir servet biriktirmiş̧lerdir. Bunların dinininde bilinen İslami görüşten farkı yoktur. Onların sahip olduğu bu ekonomik mekanizmanın temelinde yatan şey çok güçlü bir birliğe sahip olmalarıdır. Bu birliğin ahlakının gelenek - göreneklere uygunluğunu takip eden bilgin ve din adamları vardır. Toplumda onlara ayrı bir önem verilmektedir. Bu durum onları müsriflikten, tembelleşmekten, sefahata dalmaktan alı koymaktadır. Bu durumlar daha çok ideolojik olan azınlıklarda görülmektedir. Bunlara "İslam'ın püritenleri” de denilmektedir. Benzer duruma İsmailliye mezhebinde de rastlanmaktadır (Rodinson, 1978:122-123).

Rodinson'un, Weber eleştirisinden de anlaşılacağı üzere mesele tamamen, Weber'in tek taraflı okuması ve kendi metodolojisine sadık kalmayıp kıyas yolunu tercih etmesinden ileri gelmiştir. Ülgener'e göre bu durumda onda, ilk önce maddeci bir algılama ile Doğunun İslam anlayışını sürdügünü söylemesine neden olmuş ve takibinde de savaşçı bir dinden çıkarak feodal yapıya durumu bağlamasına ve en sonunda işi şehre indirgemesi sonucu gerçeğe ters düşmüştür (Ülgener, 2006a:71-72). 
Yine Ülgener, Weber'in İslami geleneğin ahlak anlayışını eleştirirken saf İslam anlayışından hareket etmeyip zaman içerisinde İ́slam geleneğinin içerisine katılmış olan alışkanlıklardan hareket ederek İslamı eleştirmesine tepki göstermiştir. Ülgener mevcut duruma şu sözlerle açıklık getirmiştir (Ülgener, 2006a:69);

“...O gözle bakınca, saf ve öz İslam'la İslam dışından kaynaklanan ahlak anlayışı arasında başından beri bir takım farkların göze çarpmaması mümkün değildir. İslam'in yanı sıra hatıra ilk planda- gerçi o da İslami şer'î kalıp kiyafette olmak üzere-Aristo'nun tradisyonel ahlak felsefesi gelir (başlıca temsilcilerini Osmanl dönemi ahlak yazarlarında bulmak mümkün). Fark görebileceğimiz kadar, şurasındadır: İslam her türlü şüpheyi kasit ve niyet tarafinda tutup eşyanın madde tarafina (Allah'in ziynet, nimet ve pak rizıkları olarak) geniş ve rahat bir yaklaşıma hak tanıdığı halde, tradisyonel ahlak bizzat madde yanı ile dünya malına çok daha dar sinırlamalar getirmiştir. Mal maddesi ile günahkâr, madde varlı̆̆ı ile saptırıcıdır. Hedef o halde: Elden geldiğince daraltılmış ve belki helalinden-zahmetsiz ve külfetsiz-her neyi önünde hazır bulursa (helal-i hazır) onunla ve sadece o kadart ile elde edilmiş olacak! Vasat ve itidal yolu; belki orta yol demek de mümkün".

Ülgener bu hususla ilgili olarak Osmanlı dönemi ahlakçılarından da örnekler göstermiştir. Özellikle de "Marifetnŏme" nin yazarı olan İbrahim Hakkı'yı göstermekte ve önermektedir. Onun yaptı̆̆1 "mel'un ve mezmûm" dünya ile"maruf ve Memduh dünya" yı bir birinden ayırıp her iki dünyanın da nimetlerinden yararlanmak için aşırıya kaçmadan "ortadaki” yolu takip etmek gerektiğine dikkat çekmiştir (Ülgener, 2006a:69). Ayrıca Ülgener, yapmış olduğu bir açıklamasında her hale uygun cevapların İslam'ın ve Sünnetin içinde yer aldığını belirtmiştir. Aristo ahlakına yönelik açıklamalarında da bu durumun örneklerine rastlamıştır (Ülgener, 2006a:68).

Buradan sonrasında Ülgener, İslam’ı okumanın anlamlı yöntemini şu şekilde açıklamıştır (Ülgener, 2006a:76); "Bütün bu tabakalaşma ve dă̆glım da bizce önemli nokta şuradadır: Illk yıllardan öteye ağırlık merkezi bir gruptan öbürüne kaydıkça dinin itikat veya en azından uygulama tarafinda da ona uygun değişmeler gözden kaçmayacaktır”. Yine Ülgener, İslamın çevrenin ve çağ değişmesine rağmen yerinden oynatamadığı mihenk taşlarına sahip olduğunu belirtir. Çünkü İslam bir şehir dinidir ve medeniyeti zaten içerisinde barındırmaktadır. Ayrıca İslam, içinde bulunduğu coğrafyanın, çölün ve onun getirisi olan bir takım unsurların olumsuz etkilerine uymamış ve bunları içerisine dahil etmemek için direnmiştir. Bununla birlikte İslam bir dışlamayı değil tam aksine hem şehrin organizasyonunu hem de çölün vurucu kuvvetini sentezleyerek bir bütün oluşturmuştur. Böylelikle İslam, feodal sistemin hayat düzeninin batıllığına ve israf anlayışına karşı koyabilmiştir. Çünkü İslam da var olan hoşgörü anlayışı aşırılığı dizginleyecek özelliktedir (Ülgener, 2006a:780).

Tüm bu açıklamaların sonucunda Ülgener, İslam'ın iktisadi gelişmeyi engelleme hususunda ki nedenler arasında en son sırada yer alacağı kanısına varmıştır (Ülgener, 2006a:84). Çünkü Ülgener'e göre İslam bir yanıyla modern ticaret araçlarına imkân tanımakta, diğer yanıyla da harp ganimetinden nafaka ve zekât borçlarının tahsiline kadar her açıdan gelişmiş bir ekonomi biçimlerine sahiptir. İslam vurgulanan ve seçilen bu halleriyle, bir tarafta piyasa ekonomisi ve serbest piyasa anlayışı diğer tarafta ise bu durumların toplumun ve insanın sahip olduğu imkanların varlığını aşacak niteliklere doğru yöneldiğini fark ettiğinde de karşıların da yer almaktadır (Ülgener, 2006a:86).

Sonuç olarak Ülgener, Weberi öncelikle metodolojik anlamda ki tutarsızlığından dolayı eleştirmiştir. Daha sonra Weber'in, İslam hakkında tek taraflı olarak sarf ettiği cümlelerinin dar kapsamlı bir okumadan ileri geldiğini söy- leyerek eleştirmiştir. Son olarak da Weber'in ideal tiplerinin tarihi süreç içerisinde ortaya çıktığı dönem ve coğ- rafyalar ile örtüşmediğini ve olanı saptırdığına dair eleştirdiği söyleyebilir.

\subsection{Sabri Fehmi Ülgener'e Yöneltilen Eleştiri}

Ülgener Doğu'nun kapitalistleşememe sorunu ele alırken Weberin “anlamacı” yöntemini benimseyerek hareket etmiştir. Kullandığı yöntemi sadece somut olarak yaşananlardan değil geçmişte oluşan olayları, edebi ve tarihi bulgulardan yararlanarak açıklamıştır. Sadece ahlaka dayalı olarak kesin yargılardan ziyade olayların altında yatan zihniyete de yer vererek mevcut durumu açıklamaya çalışmıştır. Böylece aynı yöntemi kullanmalarına rağmen Weber'den daha gerçekçi ve tutarlı sonuçlara ulaşmıştır.Yine Ülgener, Weber ve Marx'ın toplumsal alanı ele alırken takındıkları tavır gibi bilimselcilik tuzağına düşerek bireyi, farklılıkları ve tekillikleri dışlayan aşkın bir anlayışa kapılmamıştır. $\mathrm{Bu}$ anlamda Ülgener yaptığı açıklamaları ile toplumu ele alırken bireye, farklılıklara ve tekilliklere gerekli önemin verilmesinin altını çizerek içkin bir anlayışın önemini vurgulamıştır. Özellikle de doğu toplumlarının kapitalist olmadıkları yönündeki açıklamalarını haklı görmeye çalışan Marx ve 
Weber'e yönelttiği eleştirilerle bu içkin tutumun ne kadar önemli olduğunu göstermektedir. Fakat tüm bu olumlu katkılarına rağmen Ülgener'in de açıklamalarında bir takım eleştirilere maruz kalacak hatalı bir takım açıklamaları olduğunu belirtmek gerekir.

Bunlara birincisi, Ülgener'in de Weber gibi metodolojik sapmaya düşmüş olmasıdır. Burada mevcut olan metodolojik sadakatsizlik veya sapma Weber'in, İslamiyet'i eleştirirken kıyas usulüne gitmesinde ki sapmaya benzer şekildedir. Bu sapmanın en belirgin örneği de Ülgener'in, İslam'ın kapitalistleşmeye mani olmadığını ispatlamak için Kalvenizm'e karşı Melamiliği örnek göstermesinde görülmektedir.Ülgener'in Weber'i ideal tip anlayışına kapılarak gerçeği görmezden gelmesine yönelik eleştirmesine rağmen, Weber kadar kesin ifadelerle olmasa da aynı hataya kendisinin de düşmesidir. Çünkü Weber'in ideal olanı Batı için hayal edip İ̀lam anlayışını ve Doğuyu ona göre yorumlarken Ülgener ise daha olumlu bir şekilde İslam anlayışını ele almakta ve Doğunun içinde bulunduğu durumu bu çerçevede değerlendirmektedir. Ülgener'in idea anlayışına kapılıp yanılmasına örnek olarak onun Doğuda kapitalist anlayışın varlığını ispat etmede Melamiliği Kalvinizm'e karşı kullanması ile Protestanlık misyonunu onun üzerine yüklemesi gösterilebilir. Çünkü Melamilik, Ülgener'in bahsettiği anlamıyla Kalvenizmin Doğudaki tam bir yansıması değildir. Bu durumda İbn Arabi'nin Melami tasviri ile Ülgener'in Melami anlayışı karşılaştıııldığında ortaya çıkmaktadır.

Muhiyiddin İbn Arabi, Allah adamlarını üç sınıflandırmaya koyarak ele alır; "Abidler, Sufiler ve Melamiler" (İbni Arabi, 2007:271). Bu üç sınıftan ilk ikisi Melamiliğe ulaşmayı sağlayan basamaklardır. Çünkü Melamilik bunlar arasındaki en yüksek mertebedir. Melamilik, Ortodoks bir takım tarikat çevresinde örnek alınmış, benimsenmiştir. Hatta bu durumu kendi anlayışlarına da taşımaya çalışmışlardır (El- Arabi, 2011). Bu anlamda Ülgener'in bahsettiği şekliyle Melamiliğin ortaçağ tasavvuf anlayışından ahlaken ayrıldığını söylemek çok tutarlı bir söylem değildir. Yine Ülgener'in ifade ettiği şekliyle Melamilik dünyayı biçimlendirmek yahut ona ibadet için çalışmak için baktıkları bir şey değildir. Çünkü Melamilikte çalışmaktaki amaç zorunlu ihtiyaçları karşılamak ve kendini gizlemekten ileri gelmektedir. Kelime anlamı yönüyle de Melamilik bir tür kendini öne çıkarmamak, nefsi kınamak, serzenişte bulunmak anlamına gelmektedir (Bolat, 2009:458). Kalvinist anlayıştaki gibi dünya çile doldurmak için gelinmiş olan veya ne kadar çile çekersen o kadar Tanrı katında yükselirsin şeklinde değildir. Bu noktada Ülgener'in yanılsamasının yani gerçek ile ideal olanı ayırt edememesinin Melamiliğin dünya hayatı ile kurduğu ilişkiden kaynaklandığını söylemek yanlış olmayacaktır. Yine Ülgener'in aydın tipolojisinden hareket ederek sol kesimdeki Marksist veya Kemalist aydın anlayışını desteklememesi ve onun ideal aydınını o tarafta göremiyor olması da bu yanılsamasına örnek verilebilir.

Yine Ülgener'in mesafe bilincini tanımlarken yaptığı açıklamalarına da tam olarak bağlı kalmadığını söylemek gerekir. Çünkü o tarihsel süreç içerisinde insanın dünyaya karşı tutumunun madde, zaman ve mekân itibariyle ele alışına tam olarak uymamıştır. Özellikle de bu konuda fenomenlerin tarihsel bağl1lığını atlayabilmektedir. $\mathrm{Bu}$ duruma örnek olarak yine Melamiliği ele alışı verilebilir. Bunun sebebi de mevcut yanılsamanın en basit şekilde gözlemlenebiliyor olmasıdır. Ülgener, Melamiliğin çalışmayı reddetmeyen fikriyatından hareketle onu Kalvinizm ile dışsal açıdan bağdaştırmaktadır. Ancak iki değişkenin tarihsel alanda ve toplumsal tabakalaşma da kapladıkları yeri hesaba katmamıştır. Kısaca Kalvinizm kentli burjuva sınıfı arasında yer edinmiş olmasına rağmen Melamilik şehir hayatı içinde yer edinmiştir. Bir diğer şey Melamilik toprağa bağlı iken Kalvinizm ticaretle uğraşmıştır.Yine Kalvinizm farklı ekonomik ilişkileri ve toplumsal düzeni içeren bir dünya içinde hayat bulmuşken Melamilik ise mevcut dünya görüşünü çok daha ince çizgilerle ele alan tasavvufi bir yaklaşımdır.Weber'in ifadesiyle Kalvinist dünyevi bir asketizmi güderken, onu amaç edinirken Melami ise dünya dışı asketizme daha yatkındır. Buradan da anlaşılacağı üzere Melami'nin dünya ya bakış açısı ve ona olan mesafesi Kalvinist'en farklıdır (İlhan, 2014:126-127). 


\section{SONUÇ}

Sabri Fehmi Ülgener'in sağladığı katkıların ilk başında, Kemalist olgunun ve dönemin pozitivist anlayışının yol açtığı toplum mühendisliğinin çelişkilerini göstermekle birlikte, Türkiye'nin bilim camiasında hak ettiği değeri bulamamış olan anlamacı metodu tanıtmış olması da önemli bir katkıdır. Çünkü bu metot ile Ülgener gerek sosyal bilimler de gerekse fen bilimlerinde aşkıncı anlayışa (belirlenimci, statik, tekilliklere ve farklılıklara yer vermeyen anlayış) sebep olan açıklamacılığın önüne geçebilmiştir. Özellikle de pozitivizmin belirlemeciliğine anlamacı metot ile bireysel alanı ön plana çıkartarak içkin bir anlayış (her şeyi bir olanın içerisinde barındıran, ayrılıkçılığa yer vermeyen, tekillikleri ve farklılıkları da içerisinde barındıran, dinamik bir alanı ifade eden anlayış) ile karşı koyabilmiştir. Böylece insan olgusunun atlanarak yapılacak her çalışmanın hangi alanda olursa olsun eksik kaldığını göstermiştir. Bu katkıları ile anlamaya verdiği önem ve yöntemini bu yönde geliştirmesi ile Marx ve Weber'in ortak sorunu açıklamak konusundaki tutarsızlıklarını gösterdiği izlenebilmiştir.

Yine oryantalistlere karşı oksidentalizme yaptığı katkılarda atlanılmamalıdır. Tüm bunlarla birlikte Ülgener'in satır aralarında bahsettiği bazı durumlar hala günümüzde tartışma konusu olmaktadır. Örneğin onun değindiği, sistemlerin her ne kadar birbiriyle çatışıyor görünse de aslında birbirlerine tarihsel süreç içerisinde yaklaştıklarını söylemesi, günümüzün meşhur tartışması olan ideolojilerin sonu mu sözlerini akla getirmiyor değildir.Yine Ülgener'in buhranlar hususunda söylediği sözleri onun günümüzdeki iktisadi konjonktürü anlamaya yönelik çalışmalara katkı yapmaktadır.Yani günümüzdeki çalışmalardan olan iktisadi dünyanın önceden nasıl şekil alacağının tespitini konjöktürel anlanda dahil olmak üzere tam bir tutarlılıkla açılamaya odaklanan çalışmalara da göndermede bulunmaktadır. Çünkü iktisatçılar günümüzde konjonktürde değişime yol açan olayların arkasında yer alan zihniyeti anlama çabasına girmekten ziyade sadece olup bitenleri açıklamayı tercih etmektedirler.

Yine Ülgener yaşadığı dönemdeki Kemalizmin neden olduğu toplum mühendisliğinin yıkıcı ve parçalayıcı yönünü bilimsel camiada yaşadığı bunalımlar ekseninde belirtmiştir. Ülgener'in Kemalizm ve onun neden olduğu toplum mühendisliğine yönelik açıklamaları Ütopik toplum mühendisliğinin olumsuzluğunu veya yanlışlığını yıllar öncesinden işaret ederek, bölük pörçük toplum mühendisliğinin daha uygun olacağının, en azından bir toplum için bunun daha yararlı olacağının ip uçlarını da gösterir gibidir. Son olarak söylemek gerekirse Ülgener'in belirttiği gibi bilim adamı tek bir alanda saltanat süren değil, kendi alanının dışında bulunan bilimlerden de bir arka bahçe meydana getiren şahsiyet olmalıdır. Bunları yaparken de bilim ahlakını ve siyaset ahlakını birbirinden ayırabilmeli, kendi tarafsız bilim ahlakını oluşturabilmelidir.

\section{KAYNAKÇA}

AYDIN, Mustafa (1997), "Zihniyet Sorunu: Mahiyeti, Oluşumu, Türleri ve Günümüzdeki Bazı Problemleri", Tezkire: Üç Aylık Derleme, S.2(11-12), ss.123-152.

BAERT, Patrick (2010), Sosyal Bilimler Felsefesi: Pragmatizme Doğru, (Çev. Ümit Tatlıcan), Küre Yayınları, İstanbul.

BOLAT,Ali (2009), “Muhiyiddin İbnü’l Arabi'de Melamet Tasavvuru”, Tasavvuf: İlim ve Akedemik Araştırma Dergisi, S.23(İbnü’l Arabi Özel Sayıs1-2), ss.457-469.

BOTTOMORE, Tom (1990), "Marksizm ve Sosyoloji", Sosyolojik Çözümlemenin Tarihi (Ed. Tom Bottomore ve Robert Nisbet; Çev. Mete Tunçay ve Aydın Uğur), Verso Yayınları, Ankara, ss.134-164.

BULUT, Yücel (2002), Oryantalizmin Eleştirel Kısa Tarihi, Yöneliş Yayınları, İstanbul.

ÇAMLI, Ahmet Yavuz (2013), "Max Weber de Rasyonalleşme ve İktisadi Gelişme İlişsisi", Yüksek Lisans Tezi, Celal Bayar Üniversitesi Sosyal Bilimler Enstitüsü, Manisa.

ÇELIK, Celaleddin (2003), "İslam İktisat Ahlakına Dair Birbirini Tamamlayan Bakış Açıları: Weber ve Ülgener Üzerine Karşılaştırmalı Bir Inceleme”, İslam Araştırmalar Dergisi, S.16(4), ss.660-671.

ÇELIK, Celaleddin (2009), "Marx ve Weber Sosyolojisinde Oryantalist Söylem", Yüksek Lisans Tezi, Sakarya Üniversitesi Sosyal Bilimler Enstitüsü, Sakarya.

DEMIRPOLAT, Anzavur ve AKÇA, Gürsoy (2004), "Ahilik ve Türk Sosyo-Kültürel Hayatına Katkıları", Selçuk Üniversitesi Türkiyat Araştırmaları Dergisi, S.15, ss.355-376, http://sutad.selcuk.edu.tr/sutad/article/viewFile/275/265/ (Erişim Tarihi: 30.05.2016). 
EL- ARABİ, Muhammed Nur (2011), İbn Arabi’nin Günlük Duaları ve Şerhi (Çev. Mahmut Kanık), İz Yayınları, İstanbul.

ERDOĞAN, İrfan (2007), "Karl Marx: Yöntem Sorunu", İletişim Kuram ve Araştırma Dergisi, S.25, ss.257266, http://www.irfanerdogan.com/dergiweb2008/25/9markxyontem.pdf (Erişim Tarihi: 16.06.2017).

GERTH, H. Hans ve MILLS, C. Wright (1993), "Giriş: Yazar ve Yapıtı", Max Weber Sosyoloji Yazıları (Çev. Taha Parla), Hürriyet Vakfı Yayınları, İstanbul, ss.21-128.

GODELIER, Maurice (1993), Asya Tipi Üretim Tarzı (Çev. Attila Tokatlı), Sosyal Yayınları, İstanbul, 2. Bask1.

HOLFBASS, Willhelm (2004), "Special Comments", Sanskrit And «Orientalism»: Indology And Comparative Linguistics in Germany - 1750-1958 (Ed. D. T. McGetchin, P. K. J. Park, D. R. SarDesai), Manohar Publisher, New Delhi, ss.237-244.

İBNİ ARABİ, Muhammed (2007), Hatmu'ul Kur'an (Der. Abdülbaki Miftah; Çev. Vahdettin İnce), Kitsan Yayınları, İstanbul.

İLHAN, Harun (2014), "Max Weber ve Sabri Ülgener'de İktisadi Zihniyet Analizi", Yüksek Lisans Tezi, İstanbul Üniversitesi Sosyal Bilimler Enstitüsü, İstanbul.

KIZILÇELİK, Sezgin (1994), Sosyoloji Teorileri, Yunus Emre Yayınc1lık, Konya, 2. Bask1, C.2.

KORKMAZ, Cemil Hakan (2011), "Max Weber Düşüncesinde İktisadi Bakımdan Doğu-Batı Farklıllğı", Doktora Tezi, İstanbul Üniversitesi Sosyal Bilimler Enstitüsü, İstanbul.

KURT, Abdurrahman (2010), “Weber'in İslam Görüşü Üzerine Bir Değerlendirme”, Uludağ Üniversitesi İlahiyat Fakültesi Dergisi, S.19, ss.1-6.

KÜÇÜKALP, Kasım (2009), “Deleuze'ün Felsefe Kavrayışı”, Kaygı Dergisi, S.12, ss.131-147.

MARX, Karl ve ENGELS, Fredich (2003), Seçme Yayınlar 1-2, Eriş Yayınları, İstanbul.

ÖZKİRAZ, Ahmet (2003), “Sabri Fehmi Ülgener'in Max Weber Eleştirisi”, İstanbul Üniversitesi Siyasal Bilgiler Fakültesi Dergisi, S.28, ss.49-61.

ÖZÖNDER, Mehmet Cihat (1987), Kültür Bütünleşmesi ve Alt- Kültür Grupları Hakkında Düşünceler, TKAE Yayınları (Türk Kültürü Araştırmaları: Necati Akder Armağanı), Ankara.

RODINSON, Maxime (1978), İslam ve Kapitalizm (Çev. Orhan Suda), Hürriyet Yayınları, İstanbul.

SAID, Edward Wadie (1995), Şarkiyatçılık: Batı'nın Şark Anlayışları (Çev. Berna Ülner), Metis Yayınları, İstanbul.

SAYAR, Ahmet Güner (1998), Bir İktisatçının Entelektüel Portresi :Sabri Fehmi Ülgener, Eren Yayıncılık, İstanbul.

SAYAR, Ahmet Güner (2006), Makaleler, Derin Yayınc1lık, İstanbul.

SEYYAR, Ali (2007), İnsan ve Toplum Bilimleri Terimleri, Değişim Yayınları, Sakarya.

SEZER, Baykan (1988), Türk Sosyolojisinin Ana Sorunları, Sümer Kitabevi Yayınları, İstanbul.

SUNAR, Lütfi (2011), "Klasik Sosyolojinin Şarkiyatçı Kaynakları: Marx ve Weber'in Karşılaştırmalı Bir Incelemesi", İnsan ve Toplum Dergisi, S.1(2), ss.29-56.

SUNAR, Lütfi (2012), Marx ve Weber’de Doğu Toplumları, Ayrıntı Yayınları, İstanbul.

SWINGEWOOD, Alan (1998), Sosyolojik Düşüncenin Kısa Tarihi, (Çev. Osman Akınhay), Bilim ve Sanat Yayınları, Ankara.

ŞİMŞEK, Osman (2007), "Sabri Fehmi Ülgener'in Zihniyet ve Girişimcilik Anlayışına Bilgi Sosyolojisi Açısından Yaklaşım”, Sabri Fehmi Ülgener Küreselleşme Ve Zihniyet Dünyamız,(Ed. Murat Yılmaz), T.C. Kültür Ve Turizm Bakanlığı Yayınları, Ankara.

TURNER, Bryan Stanley (1997), Max Weber ve İslam (Çev. Yasin Aktay), Vadi Yayınları, Ankara, 2. Baskı.

TURNER, Bryan Stanley (2001), Marx ve Oryantalizmin Sonu (Çev. Çağatay Keskinok), Kaynak Yayınları, İstanbul, 2. Bask1. 
TÜRKDOĞAN, Orhan (2003), Türk Toplumunda Aydın Sınıfın Anotomisi, Timaş Yayınları, İstanbul.

ÜLGENER, Sabri Fehmi (1941), “İktisadi Hayatta Zihniyetin Rolü ve Tezahürleri”, İstanbul Üniversitesi İktisat Fakültesi Mecmuası, S:2(1), ss.351-380.

ÜLGENER, Sabri Fehmi (1981), Zihniyet ve Din, DerYayınları, İstanbul.

ÜLGENER, Sabri Fehmi (1983), Zihniyet, Aydınlar ve İzmler, Mayaş Yayınları, Ankara.

ÜLGENER, Sabri Fehmi (2006a), Zihniyet ve Din: İslam, Tasavvuf ve Çözülme Devri İktisat Ahlakı, Derin Yayınları, İstanbul.

ÜLGENER, Sabri Fehmi (2006b), İktisadi Çözülmenin Ahlak ve Zihniyet Dünyası, Derin Yayınları, İstanbul.

ÜLGENER, Sabri Fehmi (2006c), Zihniyet, Aydınlar ve İzm'ler: Deneme ve Araştırmalar, Derin Yayınları, İstanbul.

VEYSAL, Çetin (2010), 1900’den Günümüze Büyük Düşünürler-II, Etik Yayınları, İstanbul.

WEBER, Max (2006), Protestan Ahlakı ve Kapitalizmin Ruhu (Çev. Mily Köktürk), Bilgesu Yayınları, Ankara.

WEBER, Max (2012), Din Sosyolojisi (Ed. Ephraim Fischoff; Çev. Latif Boyacı), Yarın Yayınları, İstanbul.

YILMAZ, Hasan Kamil (2004), Tasavvuf ve Tarikatlar, Ensar Neşriyat, İstanbul.

ZARET, David (1980), "From Weber The Parsons And Scuhutz: The Eclipse Of History In Modern Social Theory", The American Journal of Sociology , Mart,Vol.85, No.5,pp. 1180-1201.

ZORLU, Abdülkadir (2006), "Sabri Fehmi Ülgener'i Yeniden Okumak”, Muhafazakar Düşünce Dergisi, S.3(9-10), ss.181-202. 